\title{
A mística cristã na contemporaneidade
}

\author{
Orientadora: Prof ${ }^{a}$. Maria Clara Lucchetti Bingemer
}

Pesquisador: Yan Piorno

Fonte: $\mathrm{CNPq}$

Introdução

Continuando nossa pesquisa sobre a grande filósofa, pensadora e mística Edith Stein, tomaremos nesta fase da pesquisa um conceito preciso que não foi por nós suficientemente trabalhado nas fases anteriores: o conceito de empatia. Trata-se de um conceito-chave no pensamento steiniano e de algo que vai influenciar sobremaneira o pensamento atual, pós-moderno, fragmentado e individualista. Edith considera ser empático uma aprendizagem de colocar-se no lugar do outro. Assim fazendo, seu pensamento nos faz aprender a dialogar com as diferenças, a ser ecumênicos e a, acima de tudo, a testemunhar uma vida de oração capaz de entusiasmar qualquer um no que se refere à mística.

\section{Objetivos}

Nosso intuito é o de desvendar nesta sociedade pós-moderna sua relação com a mística, além de observar em Edith Stein sua experiência de fé e de como esta pode contribuir para a superação da atual crise de sentidos. Partindo do contexto histórico hodierno, buscou-se nas etapas anteriores da pesquisa compreender o período de transição da modernidade para a pós-modernidade, mostrando que esta nova contextualização é marcada pela crise do ser humano devido a suas decepções e reações acerca da razão absoluta. Faz-se necessário compreender que o real sentido da mística envolve o ser humano como um todo, não só no seu aspecto religioso, mas também político e social. A mística passa a ser vista apenas no âmbito sentimental e emocional, gerando um dualismo espiritual-corporal, em que o corpo seria a "prisão da alma", sendo por isso desvalorizada socialmente. A mística e o pensamento steiniano são inseparáveis. Toda a filosofia de Edith Stein nasce de sua experiência pessoal, 
existencial, religiosa e mística. E também e não menos do seu enfoque empático, do seu desejo de pensar a partir do lugar do outro. Nosso objetivo aqui é ler a obra steiniana ou mesmo reler algumas obras da pensadora já abordadas por nós tendo como perspectiva e chave de leitura a empatia. 